\title{
Social and organizational influences on psychological hardiness: How leaders can increase stress resilience
}

\author{
Paul T Bartone
}

\begin{abstract}
Today's security forces must operate in environments of increasing complexity, uncertainty and change, a fact that has led to increased stress levels along with the challenge to adapt. For many people, such stressful conditions can lead to a range of health problems and performance decrements. But others remain healthy, showing resilience under stress. What accounts for such resilience? This paper focuses on psychological hardiness, a set of mental qualities that has been found to distinguish resilient from non-resilient people. Those high in psychological hardiness show greater commitment - the abiding sense that life is meaningful and worth living; control - the belief that one chooses and can influence his/her own future; and challenge - a perspective on change in life as something that is interesting and exciting. This paper begins with a brief discussion of the major stress sources in modern military and security operations, and the broad range of factors that can influence resilience in organizations. Next the concept of psychological hardiness is described, including theoretical background, representative research findings, and biological underpinnings. Finally, some strategies are suggested for how psychological hardiness can be built up in organizations, primarily through leader actions and policies. By focusing more attention on increasing psychological hardiness, security organizations can realize enhanced health and performance in the workforce, while also preventing many stress-related problems.
\end{abstract}

Keywords: Hardiness, Resilience, Leaders, Social influence, Security operations

\section{Introduction}

Modern life is inherently stressful, and is getting moreso as the pace of technological change continues to increase. And while much attention has been devoted to studying those who break down under stress, the majority of people appear to respond with remarkable resilience even to severe or traumatic stress [1]. What accounts for such resilience? If the factors or pathways that lead to human resiliency under stress were better understood, perhaps some of these resiliency factors could be developed or amplified in those who are initially low in resilience, and more vulnerable to stress.

This paper focuses attention on psychological hardiness, one of several potential "pathways to resilience" posited by Bonanno [1]. Following a brief discussion of the key psychological stress factors in modern military

Correspondence: bartonep@ndu.edu

Center for Technology \& National Security Policy, National Defense University, Ft. McNair, Washington, DC 20319-5062, USA and security operations, I describe the cognitive style of psychological hardiness, considering the theoretical basis as well as representative research findings. With this as background, I consider some of the ways that hardiness response patterns can be increased in persons and organizations. Based on both theoretical and empirical grounds, I argue that leaders in organizations can foster increases in the kinds of cognitions and behaviors that typify the high-hardy person's response to stressful circumstances.

\section{Psychological stress factors in military and security operations}

Military and security operations entail stressors of various kinds for the personnel involved. Combat-related stressors and the threat of violent attacks are the most obvious ones, and have received the most attention (e.g., [2]). But security operations carry additional challenges and stressors, beyond the threat of harm to life and limb. 
In the military for example, units are deploying more often and for longer periods of time, as operational demands increase while force size and budgets shrink. Increased operational requirements also lead to more frequent training exercises, planning sessions, and equipment inspections, all of which adds to the workload stress [3]. Also, more frequent deployments require more family separations, a well-recognized stressor for military personnel [4].

Given this, one avenue for reducing the stress associated with military operations is to lessen the frequency and duration of deployments. Unfortunately, such an approach is not always possible given political and strategic realities and limited resources. The military is not alone in this regard; the same is often true in other occupations and contexts. For example, following the 9/11 terrorist strike on the World Trade Center, fire, police, and other emergency and security personnel maintained continuous operations around the clock, in order to maintain security, locate survivors, and restore essential services to the affected areas. Similar situations are seen when natural disasters strike. For example, thousands of police, National Guard and disaster response workers were involved in rescuing victims, establishing security and restoring basic services in New Orleans following Hurricane Katrina in August of 2005. In such crisis situations, continuous operations and extreme efforts are necessary to save lives, and relaxing the pace of work may be considered unacceptable or even unethical.

When reducing stressful operations or activities is not a policy option, what can be done to minimize or counter the stressors associated with such operations? In order to answer this question in the case of military and security personnel, we should begin with a good understanding of the nature of the stressors encountered in operations. Extensive field research with United States military units deployed to Croatia, Bosnia, Kuwait and Saudi Arabia from 1993 through 1996, including interviews, observations and survey data, identified five primary psychological stress dimensions in modern military operations: (1)Isolation; (2)Ambiguity; (3)Powerlessness; (4)Boredom; and (5)Danger [5,6]. Today, with the greatly increased frequency and pace of deployments for U.S. forces and the long work periods involved [3], an additional significant stress factor should be added to the list: workload or "operations tempo." These dimensions are summarized in Table 1.

1. Isolation: Military personnel typically deploy to remote areas, far away from home, separated from their families, and frequently without good methods for communicating. Troops are in a strange land and culture, away from familiar surroundings. Also, fellow workers are also often strangers, since the
Table 1 Primary stressor dimensions in modern military operations

\begin{tabular}{|c|c|}
\hline Stressor & Characteristics \\
\hline \multirow[t]{5}{*}{ 1. Isolation } & -Remote location \\
\hline & -Foreign culture \& language \\
\hline & -Distant from family/friends \\
\hline & -Unreliable communication tools \\
\hline & $\begin{array}{l}\text {-Newly configured units, } \\
\text { don't know your co-workers }\end{array}$ \\
\hline \multirow[t]{5}{*}{ 2. Ambiguity } & -Unclear mission - changing mission \\
\hline & -Unclear Rules-of-Engagement (ROE) \\
\hline & -Unclear command/leadership structure \\
\hline & -Role confusion (what's my job?) \\
\hline & $\begin{array}{l}\text {-Unclear norms, standards of behavior } \\
\text { (what's acceptable here \& what is not?) }\end{array}$ \\
\hline \multirow[t]{8}{*}{ 3. Powerlessness } & -Movement restrictions \\
\hline & $\begin{array}{l}\text {-Rules of Engagement (ROE) constraints } \\
\text { on response options }\end{array}$ \\
\hline & -Policies prevent intervening, providing help \\
\hline & $\begin{array}{l}\text {-Forced separation from local culture, } \\
\text { people, events, places }\end{array}$ \\
\hline & $\begin{array}{l}\text {-Unresponsive supply chain - trouble } \\
\text { getting needed supplies \& repair parts }\end{array}$ \\
\hline & $\begin{array}{l}\text {-Differing standards of pay, movement, } \\
\text { behavior etc. for different units in area }\end{array}$ \\
\hline & $\begin{array}{l}\text {-Indeterminate deployment length - } \\
\text { don't know when we're going home }\end{array}$ \\
\hline & $\begin{array}{l}\text {-Don't know/can't influence what is } \\
\text { happening with family back home }\end{array}$ \\
\hline \multirow[t]{4}{*}{ 4. Boredom (alienation) } & $\begin{array}{l}\text {-Long periods of repetitive work } \\
\text { activities without variety }\end{array}$ \\
\hline & $\begin{array}{l}\text {-Lack of work that can be construed } \\
\text { as meaningful, important }\end{array}$ \\
\hline & $\begin{array}{l}\text {-Overall mission/purpose not understood } \\
\text { as worthwhile or important }\end{array}$ \\
\hline & -Few options for play, entertainment \\
\hline \multirow[t]{5}{*}{ 5. Danger (threat) } & -Real risk of serious injury or death, from: \\
\hline & $\begin{array}{l}\text {-enemy fire, bullets, mortars, mines, } \\
\text { explosive devices etc. }\end{array}$ \\
\hline & -accidents, including "friendly fire" \\
\hline & $\begin{array}{l}\text {-disease, infection, toxins in the } \\
\text { environment }\end{array}$ \\
\hline & $\begin{array}{l}\text {-chemical, biological, or nuclear materials } \\
\text { used as weapons }\end{array}$ \\
\hline \multirow[t]{3}{*}{ 6. Workload } & $\begin{array}{l}\text {-High frequency, duration, and pace } \\
\text { of deployments }\end{array}$ \\
\hline & $\begin{array}{l}\text {-Long work hours/days during the } \\
\text { deployments }\end{array}$ \\
\hline & $\begin{array}{l}\text {-Long work hours/days in periods before } \\
\text { and after deployments }\end{array}$ \\
\hline
\end{tabular}


deployed unit is typically a task force specially constituted for a particular mission. This creates a sense of psychological isolation.

2. Ambiguity: In modern military operations, the mission and rules-of-engagement are often unclear, or there may be multiple missions that are in conflict, or the mission changes over time. The role and purpose of the military person may be similarly unclear. Confusion and mystery in the command structure often adds to the uncertainty (who is in charge of what?). Lack of understanding of host nation language and cultural practices, and how these may impact on deployed forces, also increases the uncertainty (which norms and practices are acceptable in the host culture, and which are not?). These ambiguities can also pertain with respect to other military contingents as well as contractors in a multinational coalition force. All of this generates a highly ambiguous social environment.

3. Powerlessness: Security and operational concerns (e.g., "force protection") often lead to movement restrictions, as for example when troops are restricted from leaving their base camp. Troops may also be banned from any interaction with the local populace, and prevented from participating in familiar activities such as running/jogging for exercise, or displaying the flag. There are frequently also multiple constraints on dress and activities. They have few choices in their daily existence. Movement and communication restrictions also impede troops from learning about local culture and language, and resources that might be available locally. All of this adds to a sense of powerlessness, that one has little control over the surrounding environment. Troops may also see military personnel from other services or countries operating with different rules and privileges in the same environment, but have no explanation for these different standards. And soldiers may observe local people in need of help wounded, ill, hungry, - but be unable to proffer assistance due to movement and contact rules and rules of engagement. ${ }^{\mathrm{a}}$

4. Boredom: Modern military missions frequently involve long periods of "staying in place," often without much real work to do. As the weeks and months crawl by, troops start to get bored. To some degree, this boredom can be countered by providing more entertainment and sports activities. But the real problem of boredom is traceable to the lack of meaningful work or constructive activities to engage in. Daily tasks often take on a repetitive dullness, with a sense that nothing very important is being accomplished.
5. Danger: This dimension encompasses the real physical dangers and threats that are often present in the deployed environment, threats that can result in injury or death. Things like bullets, mines, bombs, or other hazards in the deployed setting are included here, as well as the risk of accidents, disease, and exposure to toxic substances. In current U.S. and coalition operations in Iraq and Afghanistan, this includes many hidden dangers such as suicide bombers, snipers, and "improvised explosive devices" or IEDs. This source of stress can be direct, representing threats to oneself, or indirect, representing threats to one's comrades. Exposure to severely injured or dead people, and the psychological stress this can entail, also adds to the sense of danger for troops.

6. Workload: This factor represents the increasing frequency, length, and rapid pace of deployments that many military units are encountering. Also, most deployments are characterized by a " 24 hour, 7-days a week" work schedule in which soldiers are always on duty, with no time-off. Work-related sleep deprivation is often a related feature. Training and preparation activities in the period leading up to a deployment also usually entail a heavy workload and extremely long days. The same is generally true for military units returning home from a deployment, who must work overtime to assure that all vehicles and equipment are properly cleaned, maintained and accounted for.

\section{Multiple factors can influence resilience}

While the main focus of this paper is on psychological qualities that contribute to resilience, it's also important to put this discussion in a larger context. Many factors at multiple levels can contribute to resilience, exerting some influence over how individuals behave and respond to work-related stress. Taking the military organization as an example, Figure 1 lists some of these factors at the individual, organizational policy, and organizational structure levels.

Individual level factors are relevant first of all in the selection process. These would include for example social background, personality (including psychopathology), previous experience and education, maturity, intelligence, physical fitness, and family circumstances. Training and education programs can also influence individuals in various ways, for example in building knowledge, skills and fitness. Organizational policies also can exert an important influence on resilience, in terms of how the organization and its members respond to challenging or stressful events. Here it is useful to distinguish between "macro-level" policies, such as agency rules, regulations and directives, mission statements, 


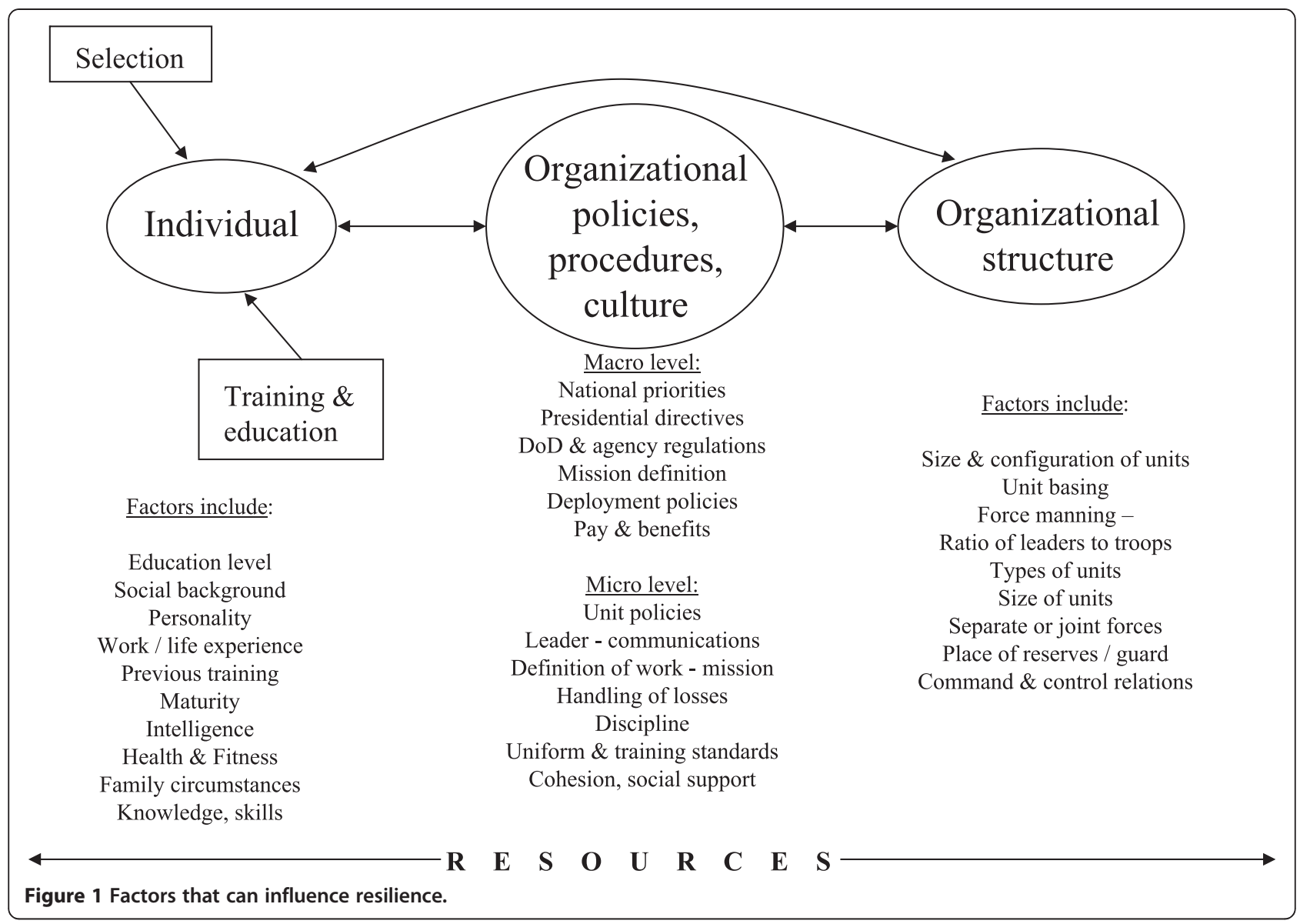

deployment and rotation policies, Rules-of-Engagement and the like, and "micro-level" policies, such as small unit policies, leader directives and communications, training schedules and policies, and so forth. At the same time it's important to recognize that some (but not all) micro-level policies and procedures are influenced rather directly by larger, macro-level policies and standards.

Organizational structural factors also have an influence on how the military organization responds to challenges. The size, type, and configuration of units may be more or less appropriate for the demands of the environment at a particular time. Other structural considerations include where units are based and how they are staffed or manned, the ratio of leaders to troops, and the integration of National Guard and Reserve forces, as well as joint and coalition forces. The integration issue here applies both in the context of specific missions, as well as regarding extended alliances (e.g., NATO coalition forces in Afghanistan). The arrows in Figure 1 serve as a reminder that these different major factors interact and influence each other as well. For example, organizational policies clearly influence (and in some cases determine) structures, while existing structures, force levels and types have an influence on policies that are developed and implemented regarding their utilization. Structures and policies have an influence on individuals in a myriad of ways, as for example when force structures and rotation policies determine when and for how long an individual will be deployed. The line labeled "Resources" at the bottom of Figure 1 is meant to indicate that all of these factors-individual, organizational policies, and organizational structuresare influence importantly by resource considerations. Budgets are limited, and what is done in any area always depends on available time and money.

What tools, strategies, or coping mechanisms can be applied in order to increase resilience or resistance to these stressors, both at the individual and organizational levels? We focus below on the psychological style known as mental hardiness, and discuss how leaders can leverage this construct to increase individual and group resiliency under stress.

\section{Psychological hardiness}

The "hardiness" theoretical model first presented by Kobasa [7] provides insight for understanding highly resilient stress response patterns in individuals and groups. 
Conceptually, hardiness was originally seen as a personality trait or style that distinguishes people who remain healthy under stress from those who develop symptoms and health problems $[7,8]$. Hardy persons have a strong sense of life and work commitment, a greater feeling of control, and are more open to change and challenges in life. They tend to interpret stressful and painful experiences as a normal aspect of existence, part of life that is overall interesting and worthwhile [9].

Rather than a personality trait, psychological hardiness is better considered a "worldview" in Adler's [10] sense, a more general framework that people apply to interpret their entire life experience. It is a generalized style of functioning that includes cognitive, emotional and behavioral features, and characterizes people who stay healthy under stress in contrast to those who develop stress-related problems. The hardy style person is also courageous in the face of new experiences as well as disappointments, and tends to be highly competent. The high-hardy person, while not impervious to the illeffects of stress, is strongly resilient in responding to highly stressful conditions.

The concept of hardiness is theoretically grounded in the work of existential philosophers and psychologists such as Heidegger [11], Frankl [12], and Binswanger [13]. It involves the creation of meaning in life, even life that is sometimes painful or absurd, and having the courage to live life fully despite its inherent pain and futility. It is a broad, generalized perspective that affects how one views the self, others, work, and even the physical world (in existential terms, Umwelt, the "around" or physical world; Mitwelt, the "with" or social world, and Eigenwelt, the world of the self or me). As early as 1967, using somewhat different terms, Maddi outlined the hardy personality type and contrasted it with the nonhardy "existential neurotic" [14]. He used the term "ideal identity" to describe the person who lives a vigorous and proactive life, with an abiding sense of meaning and purpose, and a belief in his own ability to influence things.

Since Kobasa's original report on hardiness and health in executives [7], an extensive body of research has accumulated showing that hardiness protects against the ill effects of stress on health and performance. Studies with diverse occupational groups have found that hardiness operates as a significant moderator or buffer of stress (e.g. [15-18]). Hardiness has also been identified as a moderator of combat exposure stress in Gulf War soldiers [19-21]. Psychological hardiness has emerged as a stress buffer in other military and security groups as well, including U.S. Army casualty assistance workers [22], peacekeeping soldiers [23,24], Israeli soldiers in combat training [25], Israeli officer candidates [26], and Norwegian Navy cadets [27]. Studies have found that troops who develop PTSD symptoms following exposure to combat stressors are significantly lower in hardiness, compared to those who don't get PTSD [20]. Using data from Bartone's [20] study of U.S. soldiers in the Gulf War, Figure 2 shows the typical, and rather robust interaction effect of hardiness and stress. Under low-stress conditions, those high in hardiness are fairly similar to those low in hardiness in terms of health, in this case PTSD symptoms. However, under high-stress conditions, the resiliency effects of hardiness are most apparent. Here, those high in hardiness report significantly fewer PTSD symptoms than those low in hardiness (PTSD symptoms measured by the Impact of Events Scale; [28]).

\section{Hardiness as a protective factor against stress-related disease: The psychobiology of hardiness}

Psychosocial stress is a significant risk factor in the development of many health problems, including coronary disease [29-31]. Cardiovascular disease is the leading cause of death in the world, accounting for an estimated 17.5 million deaths in 2005 or about $30 \%$ of the total [32]. Most of these deaths are from heart attacks and strokes. Many factors increase the risk of cardiovascular disease, including obesity, diet, physical inactivity, health habits, and cholesterol levels (LDL) in the blood, as well as stress (Expert Panel on Detection, Evaluation, and Treatment of High Blood Cholesterol in Adults; [33]). Furthermore, stress is associated with a number of "precursor" physiological and endocrinological changes including increased glucose and lowered insulin levels, high blood pressure, and elevated serum lipids, changes that can lead to serious disease states [34-37].

While these risk factors are well-recognized, the effect sizes are often small, suggesting that their influence is not uniform across individuals. Part of this variation may be explained by individual differences in traits and dispositions that can increase vulnerability (or resistance) to traditional risk factors. Probably the most wellstudied of these is the "Type A" behavior style, which is

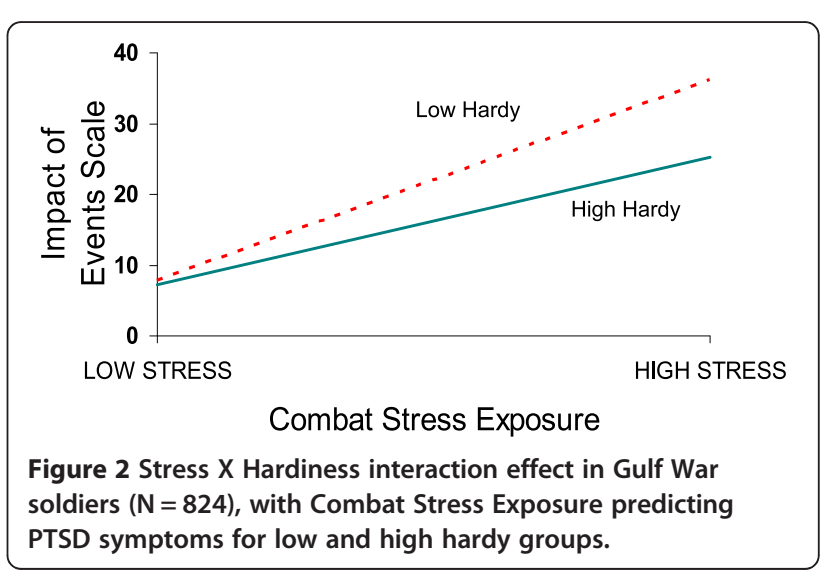


marked by impatience, competitiveness, time urgency, and hostility [38]. Many studies have linked Type A style to increased risk for Coronary Heart Disease (CHD) (e.g., $[39,40])$. However, this effect likewise is not universal, and many people who are high in the Type A pattern show no such ill effects. This suggests that other, currently unrecognized variables may be at work to influence how stressors and other risk factors impact on a person's cardiovascular status.

A relevant study by Howard, Cunningham \& Rechnitzer [41] examined both hardiness and Type A behavior pattern as potential moderators of the impact of occupational stress on several cardiovascular indicators. They found significant interaction effects between hardiness and Type A behavior, with low-hardy/high Type A persons also highest in systolic and diastolic blood pressure, triglycerides, and total cholesterol. This pattern of results suggests that persons high in hardiness are less reactive on a physiological/endocrinological level to stress, as compared to their low hardiness counterparts, who display more extreme reactions. A subsequent study by Contrada [15] also looked at hardiness and Type A style as potential moderators of cardiovascular responses to stress. Using an experimental approach to increase stress, Contrada found that systolic and diastolic blood pressures were elevated in the Type A group, and that hardiness was associated with lower diastolic blood pressure (DBP) reactivity. The lowest DBP reactivity of all was seen in the high-hardy, low Type A (Type B) subjects. Contrada took the additional step of examining the hardiness facets of Commitment, Control and Challenge, determining that the Challenge facet accounted for the lower DBP reactivity in the high hardy subjects. These two studies together suggest that hardiness is an important variable for understanding differential physiological reactivity to stress.

Additional studies have found that hardiness is related to a number of HPA hypothalamus-pituitary-adrenal axis stress response hormones [42], as well as to immune system functioning [43]. In the Zorrilla et al. [42] study, high self-esteem, hardiness and affective stability were found to be correlated with higher basal pituitary-adrenal hormone levels, notably plasma cortisol and b-endorphin. The authors suggested that high hardy persons may be less stress-reactive, and that although basal levels of HPA hormones may be somewhat elevated, hardiness is associated with less volatility in reaction to stressors. Some indirect support for this notion is taken from well established differences in stress responsiveness that track circadian patterns of glucocorticoid levels; stress responsiveness is lowest at the circadian peak of glucocorticoid levels, and highest at the circadian nadir. Similarly, high hardy persons, with consistently higher levels of basal cortisol (a potent glucocorticoid) are also less reactive to stressful conditions.
In their study of hardiness and immune functioning, Dolbier et al. [43] identified very high and low hardy persons based on DRS scores, collected blood samples, and then performed functional immune assays in vitro. They found that samples from the high hardy group showed significantly stronger functional immune response, in terms of $\mathrm{T}$ and $\mathrm{B}$ lymphocyte proliferation in response to several pathogens including Candida albicans $(\mathrm{p}<.008)$ (antigen), Mycobacterium tuberculosis - PPD ( $<$.001) (antigen), Concanavalin A (Con A) $(\mathrm{p}<.002)$ (a T-lymphocyte mitogen), and Staphylococcus enterotoxin (Staph A) ( $<$.005) (T-lymphocyte mitogen).

Another recent study found that hardiness was related to high-density lipoprotein, the type of cholesterol that appears to be protective against coronary heart disease and atherosclerosis [44]. While these findings do not demonstrate causal directionality, it may be that the mental processes employed by people high in hardiness are influencing distal bodily functions including cholesterol metabolism. This could happen through central neural pathways involving the balance between executive, rational functioning localized in the pre-frontal cortex region, and emotional responding involving limbic system structures such as the amygdala. "Executive functioning" includes threat appraisal, consideration of response options, and the decision to respond in certain ways based upon context, past experience, and long-term goals and expectations $[45,46]$. These executive - prefrontal cortex brain areas have abundant bidirectional communication pathways to a variety of limbic structures including the amygdala and hypothalamus. When confronted by novel situations and challenges, appraisals made by high hardy persons tend to be positive, with an expectation of successful coping and good outcomes. These positive appraisals would tend to maintain the inhibitory control exercised by prefrontal cortical executive function over more primitive subcortical structures and related automatic response patterns, such as the amygdala-regulated fear response. In contrast, more pessimistic (non-hardy) threat appraisals would lead to more rapid relinquishing of executive control, and reversion to more basic fear-based responses, and the extended activation states associated with sympathetic nervous system dominance. This lack of autonomic balance is known to be linked to multiple disease states, including cardiovascular disease [47]. And while specific processes remain poorly understood, recent neuroscience research has confirmed that cholesterol levels are controlled in part by central brain and neurochemical processes [48].

\section{Measuring psychological hardiness}

Early approaches to measuring hardiness were problematic in a number of ways. Hardiness was originally assessed by Kobasa [7] with an amalgam of 18 different 
scales and over 100 items to assess the dimensions of Commitment, Control and Challenge. For example, this measure and several others derived from it contained only negatively worded items, and so was really measuring non-hardiness. This increased the potential for measurement confounding with negative factors like neuroticism and depression [49]. In addition, many studies failed to find the three core hardiness factors of commitment, control and challenge. These measurement problems led to the creation of a new, improved hardiness scale developed by Bartone for use in a study of stress and health in Chicago bus drivers [50]. This hardiness scale was further refined into a 45-item measure (the Dispositional Resilience Scale-DRS) reported in 1989 [22]. Additional psychometric work led to shorter 30-item and 15-item versions [51]. The DRS has been used extensively in U.S. military and non-military samples, with excellent results (eg., [22,24]). In his review of hardiness theory and research, Funk [52] recommended the DRS as the best available hardiness measure. Also using the DRS, Sinclair \& Tetrick [53] confirmed a factor structure of three facets, commitment control and challenge, nested under a more general hardiness construct. The short DRS-15 scale was translated into Norwegian in 1998, and has since been used in multiple studies in Norway [27,54]. The DRS-15 scale has been further improved in cross-cultural studies with Norwegian and American samples $[55,56] .^{\mathrm{b}}$

\section{Psychological hardiness as a framework for understanding positive leader influence}

How does hardiness increase resiliency to stress? While the underlying mechanisms are still not fully understood, a critical aspect of the hardiness resiliency mechanism likely involves the interpretation, or the meaning that people attach to events around them and their own place in the experiential world. As discussed earlier, this involves the executive mental functions of memory, recognition, appraisal and judgment. High hardy people typically interpret experience as (1)overall interesting and worthwhile, (2)something they can exert control over, and (3)challenging, presenting opportunities to learn and grow. In organized work groups such as the military and many security organizations, this "meaningmaking" process is something that can be influenced by leader actions and policies. Military units by their nature are group-oriented and highly interdependent. Common tasks and missions are group ones, and the hierarchical authority structure frequently puts leaders in a position to exercise substantial control and influence over subordinates. By the policies and priorities they establish, the directives they give, the advice and counsel they offer, the stories they tell, and perhaps most importantly the examples they set, leaders may alter the manner in which their subordinates interpret and make sense of experiences. Some empirical support for this notion comes from a study by Britt, Adler and Bartone [24], who found (using structural equation modeling) that hardiness increases the perception of meaningful work, which in turn increases the perception of positive benefits associated with a stressful military deployment to Bosnia.

Many writers have commented on how social processes can influence the creation of meaning by individuals. For example, Janis [57] used the term "groupthink" to describe how people in groups can come to premature closure on issues, with multiple individuals conforming to whatever is the dominant viewpoint in the group. Berger and Luckmann [58] argue that "reality" or perceptions of individuals reflect "social constructions," an incorporation into the individual mind of social definitions of the world. Karl Weick [59] discusses the process by which organizational policies and programs can influence how individuals within the organization "make sense of" or interpret their experiences, particularly at work. Even Gordon Allport [60], distinguished American personality psychologist, viewed individual meaning as often largely the result of social influence processes. Peers, leaders, and entire work units or organizational cultures can influence how experiences get interpreted. In particular, leaders who are high in hardiness themselves can exert substantial influence on those around them to process stressful experiences in ways characteristic of high hardy persons.

Thus, the operative power of psychological hardiness to lessen the ill-effects of stressful experiences is related to the particular interpretations of such experiences that are typically made by the hardy person. If a stressful or painful experience can be cognitively framed and madesense-of within a broader perspective which holds that all of existence is essentially interesting, worthwhile, a matter of personal choice, and providing chances to learn and grow, then the stressful experience can have beneficial psychological effects instead of harmful ones. In a small group context, leaders are in a unique position to shape how stressful experiences are understood by members of the group. The leader who, through example and discussion, communicates a positive construction or re-construction of shared stressful experiences, may exert an influence on the entire group in the direction of his/her interpretation of experience.

Leaders who are high in hardiness likely have a greater impact in their groups under high-stress conditions, when by their example, as well as by the explanations they give to the group, they encourage others to interpret stressful events as interesting challenges which can be met, and in any case provide opportunities to learn. This process itself, as well as the positive result (a shared 
understanding of the stressful event as something worthwhile and beneficial) could be expected to also generate an increased sense of shared values, mutual respect, and cohesion. Further support for this interpretation comes from a study showing that hardiness and leadership interact to affect small group cohesion levels following a rigorous military training exercise [27]. This interaction effect signifies that the positive influence of leaders on the growth of unit cohesion is greater when hardiness levels in the unit are high. This suggests that effective leaders encourage positive interpretations of stressful events and increase group solidarity, especially in a context of higher psychological hardiness levels.

Although more research is needed on this issue, there is now sufficient evidence to support the view that leaders can increase high-hardiness response patterns within their organizations, and to provide a preliminary sketch of how the high-hardy leader behaves in order to influence hardiness and stress resilience in the organization. The prototypical hardy leader: (1) Leads by example, providing subordinates with a role model of the hardy approach to life, work, and reactions to stressful experiences. Through actions and words, he/she demonstrates the strong sense of commitment, control, and challenge, and a way of responding to stressful circumstances that demonstrates stress can be valuable, and that stressful events always at least provide the opportunity to learn and grow; (2) facilitates "hardy" group sense making of experience, in how tasks, missions are planned, discussed, and executed, and also as to how mistakes, failures, and casualties are spoken about and interpreted. While most of this sense making influence occurs through normal day-to-day interactions and communications, occasionally it can happen in the context of more formal "After-Action Reviews," or debriefings that can focus attention on events as learning opportunities and create shared positive constructions of events and responses around events; ${ }^{\mathrm{c}}$ (3) seeks out (creates if necessary) meaningful/challenging group tasks, and then capitalizes on group accomplishments by providing recognition, awards, and opportunities to reflect on and magnify positive results (e.g., photographs, news accounts, and other tangible mementos).

In work groups such as the military and security organizations, where individuals are regularly exposed to a range of stressors and hazards, leaders are in a unique position to shape how stressful experiences are made sense of, interpreted and understood by members of the group. The leader who by example, discussion, and established policies communicates a positive construction or reconstruction of shared stressful experiences, exerts a positive influence on the entire group in the direction of his/her interpretation of experience - toward more resilient and hardy sense-making. And while leadership is of core importance, multiple other factors also may influence how individuals make sense of experiences. For example, policies and regulations throughout the organization can have the effect not only of increasing or decreasing stress levels, but may also directly and indirectly influence hardiness commitment, control and challenge tendencies in employees. A better knowledge of these various factors will permit more effective approaches to building stress resilience not just in security organizations, but anywhere people are exposed to highly stressful circumstances.

\section{Endnotes}

a Other studies have also identified powerlessness as a damaging influence for soldiers on peacekeeping operations For example, Weisaeth \& Sund [61] found that in Norwegian soldiers serving in Lebanon under the UNIFIL United Nations peacekeeping mission, the feeling of being powerless to act or intervene when witnessing some atrocity was a main contributor to post-traumatic stress symptoms.

b The DRS-15 is available at www.kbmetrics.com.

c An NIMH report on best practices for early psychological interventions following mass violence events [62] noted great confusion regarding the term "debriefing." The authors recommend that the term "debriefing" be reserved for operational after-action reviews, and not be applied to psychological treatment interventions such as Critical Incident Stress Debriefing [63]. For groups such as the military, after-action group debriefings, properly timed and conducted and focused on events rather than emotions and reactions, can have great therapeutic value for many participants by helping them to place potentially traumatizing events in a broader context of positive meaning [64].

Competing interests

The author declares no competing interests.

\section{Authors' contributions}

The primary author is respnsible for the research and all aspects of the manuscript.

Received: 27 December 2011 Accepted: 7 September 2012 Published: 8 November 2012

\section{References}

1. GA Bonanno, Loss, trauma and human resilience: Have we underestimated the human capacity to thrive after extremely aversive events? Am Psychol 59, 20-28 (2004)

2. CW Hoge, CA Castro, SC Messer, D McGurk, DI Cotting, RL Koffman, Combat duty in Iraq and Afghanistan, mental health problems, and barriers to care. N Engl J Med 351, 13-22 (2004)

3. C Castro, A Adler, OPTEMPO: Effects on soldier and unit readiness. Parameters 29, 86-95 (1999)

4. DB Bell, J Bartone, PT Bartone, WR Schumm, PA Gade, USAREUR family support during Operation Joint Endeavor: Summary report (ARI Special Report 34) (U. S. Army Research Institute for the Behavioral and Social Sciences, Alexandria, VA, 1997), p. ADA339016 
5. PT Bartone, Psychosocial stressors in future military operations (Paper presented at the Cantigny Conference Series on Future of Armed Conflict, Wheaton, Illinois, 2001)

6. PT Bartone, AB Adler, MA Vaitkus, Dimensions of psychological stress in peacekeeping operations. Military Medicine 163, 587-593 (1998)

7. SC Kobasa, Stressful life events, personality, and health: An inquiry into hardiness. J Personal Soc Psychol 37, 1-11 (1979)

8. SR Maddi, SC Kobasa, The hardy executive (Dow Jones-Irwin, Homewood, IL, 1984)

9. SC Kobasa, SR Maddi, Existential personality theory, in Existential Personality Theories, ed. by R Corsini (Peacock, Itasca, IL, 1977), pp. 243-276

10. A Adler, The Individual Psychology of Alfred Adler, in, ed. by HL Ansbacher, RR Ansbacher (Harper Torchbooks, New York, 1956)

11. M Heidegger, Being and time (Harper Collins Publishers, New York, 1986)

12. V Frankl, The doctor and the soul (Knopf, New York, 1960)

13. L Binswanger, Being in the world: Selected papers of Ludwig Binswanger (Basic Books, New York, 1963)

14. SR Maddi, The existential neurosis. J Abnorm Psychol 72, 311-325 (1967)

15. RJ Contrada, Type A behavior, personality hardiness, and cardiovascular responses to stress. J Personal Soc Psychol 57, 895-903 (1989)

16. SC Kobasa, SR Maddi, S Kahn, Hardiness and health: A prospective study. J Personal Soc Psychol 42, 168-177 (1982)

17. DL Roth, DJ Wiebe, RB Fillingim, KA Shay, Life events, fitness, hardiness, and health: A simultaneous analysis of proposed stress-resistance effects. J Personal Soc Psychol 57, 136-142 (1989)

18. DJ Wiebe, Hardiness and stress moderation: A test of proposed mechanisms. J Personal Soc Psychol 60, 89-99 (1991)

19. PT Bartone, Hardiness as a resiliency factor for United States forces in the Gulf War, in Posttraumatic stress intervention: Challenges, issues, and perspectives, ed. by JM Violanti, D Paton, C Dunning (C. Thomas, Springfield, |llinois, 2000), pp. 115-133

20. PT Bartone, Hardiness protects against war-related stress in Army reserve forces. Consulting Psychology Journal 51, 72-82 (1999)

21. PT Bartone, Psychosocial predictors of soldier adjustment to combat stress (Paper presented at the Third European Conference on Traumatic Stress, Bergen, Norway, 1993)

22. PT Bartone, RJ Ursano, KW Wright, LH Ingraham, The impact of a military air disaster on the health of assistance workers: A prospective study. J Nerv Ment Dis 177, 317-328 (1989)

23. PT Bartone, Stress and hardiness in U.S. peacekeeping soldiers (Paper presented at the annual convention of the American Psychological Association, Toronto, Ontario, 1996)

24. TW Britt, AB Adler, PT Bartone, Deriving benefits from stressful events: The role of engagement in meaningful work and hardiness. J Occup Heal Psychol 6, 53-63 (2001)

25. V Florian, M Mikulincer, O Taubman, Does hardiness contribute to mental health during a stressful real life situation? The role of appraisal and coping. J Personal Soc Psychol 68, 687-695 (1995)

26. M Westman, The relationship between stress and performance: The moderating effect of hardiness. Hum Perform 3, 141-155 (1990)

27. PT Bartone, BH Johnsen, J Eid, JC Laberg, W Brun, Factors influencing small unit cohesion in Norwegian Navy officer cadets. Mil Psychol $14,1-22(2002)$

28. M Horowitz, N Wilner, W Alvarez, Impact of Events Scale: A measure of subjective stress. Psychosomatic Medicine 41, 209-218 (1979)

29. M Kivimäki, P Leino-Arjas, R Luukkonen, H Riihimäki, J Vahtera, J Kirjonen, Work stress and risk of cardiovascular mortality: Prospective cohort study of industrial employees. British Medical Journal 325, 857-860 (2002)

30. DS Krantz, DS Sheps, RM Carney, BH Natelson, Effects of Mental Stress in Patients with Coronary Artery Disease: Evidence and Clinical Implications. JAMA 283, 1800-1802 (2000)

31. TW Smith, JM Ruiz, Psychosocial influences on the development and course of coronary heart disease: Current status and implications for research and practice. J Consult Clin Psychol 70, 548-568 (2002)

32. World Health Organization, cardiovascular diseases data for 2005. http://www.who.int/cardiovascular_diseases/en/ (accessed 28 August, 2008)

33. WP Castelli, RJ Garrison, PW Wilson, RD Abbott, S Kalousdian, BW Kannel, Incidence of coronary heart disease and lipoprotein cholesterol levels: The Framingham Study. JAMA 256, 2835-2838 (1986)
34. NS Bhacca, Five hourly measurements of serum cholesterol levels: A new methodology to assess and evaluate stress, good health and disease. Medical Hypotheses 54, 962-968 (2000)

35. RB Singh, H Mori, Risk factors for coronary heart disease: Synthesis of a new hypothesis through adaptation. Medical Hypotheses 39, 334-341 (1992)

36. A Steptoe, L Brydon, Associations between acute lipid stress responss and fasting lipid levels 3 years later. Heal Psychol 24, 601-607 (2005)

37. WR Ware, High cholesterol and coronary heart disease in younger men: The potential role of stress induced exaggerated blood pressure response. Medical Hypotheses 70, 543-547 (2007)

38. M Friedman, R Rosenman, Type A Behavior and Your Heart (Knopf, New York, 1974)

39. T Cooper, T Detre, SM Weiss, JD Bristow, R Carleton, HP Dustan, RS Eliot, M Feinleib, MJ Jesse, FJ Klocke, GE Schwartz, JL Shields, RA Stallones, Coronaryprone behavior and coronary heart disease: a critical review. Circulation 63, 1199-1215 (1981)

40. BK Houston, CR Snyder, Type A behavior pattern: Research, theory, and practice (Wiley, New York, 1988)

41. JH Howard, DA Cunningham, PA Rechnitzer, Personality (hardiness) as a moderator of job stress and coronary risk in Type A individuals: A longitudinal study. J of Behavioral Medicine 9, 229-244 (1986)

42. EP Zorrilla, RJ DeRubeis, E Redei, High self-esteem, hardiness and affective stability are associated with higher basal pituitary -adrenal hormone levels. Psychoneuroendocrinology 20, 591-601 (1995)

43. CL Dolbier, RR Cocke, JA Leiferman, MA Steinhardt, SJ Schapiro, PN Nehete, JE Perlman, J Sastry, Differences in immune responses of high vs. low hardy healthy individuals. J of Behavioral Medicine 24, 219-229 (2001)

44. PT Bartone, A Spinosa, J Robb, Psychological hardiness is related to baseline high-density lipoprotein (HDL) cholesterol levels (Presented at the Association for Psychological Science annual convention, San Francisco, CA, 2009)

45. E Koechlin, G Basso, P Pietrini, S Panzer, J Grafman, The role of the anterior prefrontal cortex in human cognition. Nature 399, 148-151 (1999)

46. Y Suchy, Executive functioning: Overview, assessment, and research issues for non-neuropsychologists. Annals of Behavioral Medicine 37, 106-116 (2009)

47. JF Thayer, RD Lane, The role of vagal function in the risk for cardiovascular disease and mortality. Biol Psychol 74, 224-242 (2007)

48. D Perez-Tilve, SM Hofmann, J Basford, R Nogueiras, PT Pfuger, JT Patterson E Grant, HE Wilson-Perez, NA Granholm, M Arnold et al., Melanocortin signaling in the CNS directly regulates circulating cholesterol. Nat Neurosci $13,877-882(2010)$

49. SC Funk, BK Houston, A critique analysis of the hardiness scale's validity and utility. J Personal Soc Psychol 53, 572-578 (1987)

50. PT Bartone, Predictors of stress-related illness in city bus drivers. Journal of Occupational Medicine 31, 657-663 (1989)

51. PT Bartone, A short hardiness scale (Paper presented at the Annual Convention of the American Psychological Society, New York, 1995)

52. SC Funk, Hardiness: A review of theory and research. Heal Psychol 11, 335-345 (1992)

53. RR Sinclair, LE Tetrick, Implications of item wording for hardiness structure, relation with neuroticism, and stress buffering. J Res Personal 34 $1-25(2000)$

54. BH Johnsen, J Eid, PT Bartone, Psykologisk "hardførhet": Kortversjonen av The Short Hardiness Scale. Tidsskrift for Norsk Psykologforening 41, 476-477 (2004)

55. PT Bartone, BH Johnsen, J Eid, H Molde, SW Hystad, JC Laberg, DIF-Differential Item Functioning analysis of Norwegian and American hardiness measures (Presented at the Association for Psychological Science annual convention, Washington, DC, 2007)

56. SW Hystad, J Eid, BH Johnsen, JC Laberg, PT Bartone, Psychometric properties of the revised Norwegian dispositional resilience (hardiness) scale. Scand J Psychol 51, 237-245 (2010)

57. I Janis, Groupthink, 2dth edn. (Houghton Mifflin, Boston, 1982)

58. PL Berger, T Luckmann, The social construction of reality (Doubleday, Garden City, NY, 1966)

59. KE Weick, Sensemaking in organizations (Sage, Thousand Oaks, CA, 1995)

60. GW Allport, The historical background of social psychology, in Handbook of Social Psychology, ed. by G Lindzey, E. Aronson, vol. 1, 3rd edn. (Random House, New York, 1985), pp. 1-46 
61. L Weisaeth, A Sund, Psychiatric problems in UNIFIL and the UN-Soldier's stress syndrome. International Review of Army, Air Force and Navy Medical Service $55,109-116$ (1982)

62. National Institute of Mental health, Mental health and mass violence: Evidence-based early psychological intervention for victims/survivors of mass violence. A workshop to reach consensus on best practices. NIH Publication No. 02-5138 (U.S. Government Printing Office, Washington, DC, 2002). also at www.nimh.nih.gov/research/massviolence.pdf

63. JT Mitchell, GS Everly, Critical incident stress management and critical incident stress debriefing: Evolutions, effects, and outcomes, in Psychological debriefing: Theory, practice and evidence, ed. by B Raphael, JP Wilson (Cambridge University Press, Cambridge, England, 2000), pp. 71-90

64. PT Bartone, Einsatzorientierte Nachbesprechung (Debriefing): Was jeder militärische Führer wissen sollte (Event-oriented debriefing following military operations: What every leader should know), in Streßbewältigung und Psychotraumatologie im UN- und humanitären Hilfseinsatz (Coping with stress and psychological trauma in UN and peacekeeping operations), ed. by T Sporner (Beta Verlag, Bonn, 1997), pp. 126-133

doi:10.1186/2190-8532-1-21

Cite this article as: Bartone: Social and organizational influences on psychological hardiness: How leaders can increase stress resilience. Security Informatics 2012 1:21.

\section{Submit your manuscript to a SpringerOpen ${ }^{\circ}$ journal and benefit from:}

- Convenient online submission

- Rigorous peer review

- Immediate publication on acceptance

- Open access: articles freely available online

- High visibility within the field

- Retaining the copyright to your article 